\title{
Uma defesa do aborto
}

A maior parte da oposição ao aborto baseia-se na premissa de que o feto é um ser humano, uma pessoa, desde o momento da concepção. ${ }^{1}$ A meu ver, a argumentação a favor dessa premissa não é bem feita. Vejamos, por exemplo, o argumento mais comum. Pede-se que observemos que o desenvolvimento de um ser humano é contínuo da concepção até a infância, passando pelo nascimento; a seguir afirma-se que traçar uma linha, escolher um ponto desse desenvolvimento e dizer "antes deste ponto a coisa não é uma pessoa, depois deste ponto é uma pessoa” consiste em fazer uma escolha arbitrária, escolha para a qual não se podem dar boas razões inerentes à natureza das coisas. Conclui-se que o feto é, ou que pelo menos seria melhor dizermos que é, uma pessoa desde o momento da concepção. Mas esta conclusão não é evidente. Podem-se fazer afirmações semelhantes a respeito do desenvolvimento de uma bolota até tornar-se um carvalho, e daí não decorre que as bolotas sejam carvalhos, ou que seria melhor dizer que são. Os argumentos que têm essa forma às vezes são chamados de "argumentos da derrapagem" - a expressão talvez seja autoexplicativa -, e é consternador que os oponentes ao aborto se baseiem tanto neles, e de maneira tão acrítica.

No entanto, tendo a concordar que a perspectiva de "traçar uma linha" no desenvolvimento do feto parece estúpida. Também tendo a pensar que prova-

Devo muito a James Thomson por sua discussões, críticas e muitas sugestões úteis. Do original "A defense of abortion", publicado em Philosophy \& Public Affairs (vol. 1, n. 1, 1971). Direitos autorais concedidos por John Wiley \& Sons, Inc. Traduzido por Sieni Maria Campos. Revisão da tradução por Flávia Biroli. 
velmente devamos concordar que o feto já se tornou uma pessoa humana bastante antes do nascimento. De fato, é uma surpresa ver como o feto começa a adquirir características humanas cedo em sua vida. Na décima semana, por exemplo, já tem rosto, braços e pernas, dedos nas mãos e nos pés; tem órgãos internos, e a atividade cerebral é detectável (Callahan, 1970, p. 373). ${ }^{2}$ Contudo, creio que a premissa é falsa, que o feto não é uma pessoa desde o momento da concepção. Um ovo recém fertilizado, um grupo de células recém implantado, não é mais uma pessoa do que uma bolota é um carvalho. Mas não vou discutir nada disso, pois me parece ser de grande interesse perguntar o que aconteceria se, a título argumentativo, aceitássemos a premissa. Como, precisamente, devemos passar dali à conclusão de que o aborto é moralmente inadmissível? Os oponentes ao aborto costumam dedicar a maior parte de seu tempo a provar que o feto é uma pessoa, e quase nenhum a explicar o passo que leva daqui à inadmissibilidade do aborto. Talvez considerem a passagem simples e óbvia demais para exigir muito comentário. Ou talvez, em vez disso, simplesmente estejam sendo econômicos no argumento. Muitos dos que defendem o aborto baseiam-se na premissa de que o feto não é uma pessoa, mas apenas uma pequena quantidade de tecido que se tornará uma pessoa ao nascer; e por que apresentar mais argumentos do que o necessário? Seja qual for a explicação, sugiro que o passo que dão não é nem fácil nem óbvio, que exige um exame mais minucioso do que normalmente é feito, e que, quando fizermos este exame minucioso, seremos propensos a rejeitá-la.

* Proponho então que aceitemos que o feto é uma pessoa desde o momento da concepção. Como o argumento se desenrola a partir daí? Algo assim, imagino. Toda pessoa tem direito à vida. Portanto, o feto tem direito à vida. Não há dúvida de que a mãe tem o direito de decidir o que acontecerá em e com seu corpo; todo mundo aceitaria isto. Porém o direito à vida de uma pessoa é certamente mais forte e mais estrito do que o direito da mãe de decidir o que acontece em e com seu corpo e, portanto tem mais peso. Assim, o feto não pode ser morto; não se pode fazer um aborto.

Parece plausível. Mas agora lhes peço que imaginem isto. Você acorda de manhã e descobre que está na cama ao lado de um violinista inconsciente. Um violinista inconsciente famoso. Descobriu-se que ele sofria de uma 
doença renal fatal, e a Sociedade dos Amantes da Música vasculhou todos os prontuários médicos disponíveis e constatou que só você tem o tipo sanguíneo compatível para ajudá-lo. Assim sendo, a Sociedade a sequestrou e, na noite anterior, o sistema circulatório do violinista foi conectado ao seu, de forma que os seus rins pudessem ser usados para extrair o veneno do sangue dele e também do seu. O diretor do hospital agora lhe diz: "Veja, lamentamos a Sociedade dos Amantes da Música ter feito isso com você - se tivéssemos sabido, nunca teríamos permitido. Mas o fato é que eles fizeram e o violinista agora está conectado com você. Desconectar você significaria matá-lo. Mas não se preocupe, é só por nove meses. No fim desse prazo estará recuperado e poderá ser desconectado de você com segurança." Você é moralmente obrigada a aceitar essa situação? Não há dúvida de que seria muito bacana de sua parte, uma grande bondade. Mas você tem de assentir? E se não fossem nove meses, mas nove anos? Ou mais tempo ainda? E se o diretor do hospital dissesse: "É falta de sorte, concordo, mas você agora tem de ficar na cama, com o violinista conectado a você, pelo resto da sua vida. Porque, lembrem-se disto: toda pessoa tem direito à vida, e os violinistas são pessoas. Claro que você tem o direito de decidir o que acontece em e com o seu corpo, mas o direito de uma pessoa à vida tem mais peso do que o seu direito de decidir o que acontece em e com o seu corpo. Assim sendo, você nunca poderá ser desconectada dele". Imagino que você consideraria isso como ultrajante, o que sugere que algo está realmente errado no argumento aparentemente plausível que mencionei agora pouco.

Neste caso, é claro, você foi sequestrada; não se apresentou como voluntária para a operação que conectou o violinista aos seus rins. Será que os que se opõem ao aborto com base nos fundamentos que mencionei podem abrir uma exceção para gestações decorrentes de estupro? Certamente. Podem dizer que as pessoas só têm direito à vida se sua existência não tiver sido gerada por estupro; ou podem dizer que todas as pessoas têm direito à vida, mas que algumas têm menos direito à vida do que outras; em particular, aquelas cuja existência foi gerada por estupro têm menos direito. Mas o som dessas afirmações é bastante desagradável. Sem dúvida, a questão de se você tem direito à vida, ou de quanto desse direito você tem, não deve ativar a questão de se você é ou não produto de estupro. E, na verdade, as pessoas que se opõem ao aborto com base no que apontei não fazem essa distinção e, portanto, não abrem exceção em caso de estupro. 
Também não abrem exceção para casos em que a mãe tem de passar os nove meses de gestação na cama. Concordam que seria uma grande pena, e difícil para a mãe; mas, mesmo assim, todas as pessoas têm direito à vida, o feto é uma pessoa, e assim por diante. Na verdade, desconfio que não abririam uma exceção para um caso em que, milagrosamente, a gestação durasse nove anos, ou mesmo o resto da vida da mãe.

Alguns nem fariam uma exceção para casos em que o prosseguimento da gestação provavelmente encurtasse a vida da mãe; consideram o aborto inadmissível até mesmo para salvar a vida da mãe. Esses casos são muito raros hoje, e numerosos oponentes do aborto não aceitam essa visão extrema. Mesmo assim, é um bom ponto de partida: diversos pontos de interesse surgem em relação a ele.

1. Vamos chamar de "visão extrema" o ponto de vista de que o aborto é inadmissível até para salvar a vida da mãe. Primeiro quero sugerir que esta não provém do argumento que mencionei anteriormente sem o acréscimo de algumas premissas bastante fortes. Suponhamos que uma mulher engravide e depois saiba que tem um problema cardíaco tal que morreria se levasse a gestação a termo. O que se pode fazer por ela? O feto, sendo uma pessoa, tem direito à vida, mas a mãe também é uma pessoa, de forma que tem direito à vida. Ambos supostamente têm igual direito à vida. Como se imagina que daí decorra que não se possa fazer um aborto? Se a mãe e o filho têm igual direito à vida, será que talvez não devêssemos tirar a sorte? Ou talvez devêssemos acrescentar ao direito da mãe à vida o seu direito de decidir o que acontece em e com seu corpo, que todos parecem dispostos a reconhecer - então a soma de seus direitos agora não teria mais peso do que o direito do feto à vida?

$\mathrm{O}$ argumento mais conhecido neste caso é o seguinte. Dizem-nos que fazer o aborto seria matar diretamente ${ }^{3}$ a criança, ao passo que não fazer nada não seria matar a mãe, mas apenas deixá-la morrer. Além disso, ao matar o filho, estaríamos matando uma pessoa inocente, pois a criança não cometeu crime algum, e não visa matar sua mãe. E depois esta discussão pode continuar de várias maneiras. (i) Mas como matar diretamente uma

\footnotetext{
O termo "direto" nas discussões a que me refiro é um termo técnico. O que se quer dizer por "morte direta" é, grosso modo, matar como um fim em si, ou matar como um meio para algum fim como, por exemplo, o fim de salvar a vida de outra pessoa. Ver, a seguir, um exemplo deste uso na nota 6.
} 
pessoa inocente é sempre e absolutamente inadmissível, não se pode fazer o aborto. Ou, (2) como matar diretamente uma pessoa inocente é assassinato e é sempre e absolutamente inadmissível, não se pode fazer o aborto. ${ }^{4} \mathrm{Ou}$, (3) como o dever de não matar diretamente uma pessoa inocente é mais estrito do que o dever de evitar que uma pessoa morra não se pode fazer o aborto. Ou, (4) se a única opção é entre matar diretamente uma pessoa inocente ou deixar uma pessoa morrer, deve-se preferir deixar a pessoa morrer e, portanto, não se pode fazer o aborto. ${ }^{5}$

Algumas pessoas parecem ter pensado que estas não são novas premissas a serem acrescentadas para chegar à conclusão, mas que são decorrentes do próprio fato de que uma pessoa inocente tem direito à vida. ${ }^{6}$ Mas me parece que é um erro, e a maneira mais simples de mostrá-lo talvez seja apontar que, embora, sem dúvida, devamos reconhecer que as pessoas inocentes têm direito à vida, as teses de (1) a (4) são falsas. Vejamos (2), por exemplo. Se matar diretamente uma pessoa inocente é assassinato e, portanto, sempre inadmissível, então a mãe matar diretamente a pessoa inocente que está dentro dela é assassinato e, portanto, inadmissível. Mas não se pode pensar seriamente tratar-se de assassinato se a mãe faz um aborto para salvar sua própria vida. Não se pode dizer seriamente que ela não deve fazê-lo, que ela deve esperar passivamente sua própria morte. Vejamos de novo o caso que implica você e o violinista. Ali está você, na cama com o violinista, e o diretor do hospital lhe diz: "É tudo muito angustiante, e sou profundamente solidário com você, mas isto está exigindo demais dos seus rins e daqui a

${ }_{4}$ Cf. Encyclical letter of pope Pius XI on Christian marriage, (s.d., p. 32): "já dissemos (...) quanta compaixão sentimos pela mãe a quem o cumprimento do seu dever natural expõe a graves perigos da saúde e até da própria vida; mas que causa poderá jamais bastar para desculpar de algum modo a morte direta do inocente? Porque é desta que aqui se trata". Noonan Jr. (1970, p. 43) lê o trecho assim: "Que causa pode-se invocar para desculpar, seja como for, a morte direta do inocente? Porque é desta que aqui se trata".

5 A tese em (4) é mais fraca, de maneira interessante, do que as que figuram em (1), (2) e (3): excluem o aborto até em casos em que mãe $e$ filho morrerão se o aborto não for realizado. Em contraste, os defensores do ponto de vista expresso em (4) poderiam dizer, de forma coerente, que não se deve preferir deixar duas pessoas morrerem a matar uma delas.

6 Cf. o seguinte trecho de Pio XII, na Carta à sociedade católica italiana de parteiras: "O bebê no seio materno recebe a luta pela vida imediatamente de Deus - Portanto, não há homem, autoridade humana, ciência nem indicação médica, eugênica, social, econômica ou moral que possa determinar ou reconhecer um fundamento jurídico válido para a disposição direta e deliberada de uma vida humana inocente, ou seja, uma disposição que vise à sua destruição seja como fim, seja como meio para outro fim, talvez em si não ilícito. O bebê, ainda não nascido, é um ser humano no mesmo grau e pela mesma razão que a mãe" (apud Noonan, 1970, p. 45). 
um mês você estará morta. Mas mesmo assim você tem de ficar onde está. Porque desconectá-la seria matar diretamente um violinista inocente, e isso é assassinato, e isso é inadmissível". Se algo é verdade neste mundo, é que você não cometeria assassinato, não faria o que é inadmissível, se desconectasse os seus rins daquele violinista para salvar sua vida.

O principal foco de atenção nos textos sobre aborto tem sido o que um terceiro pode ou não pode fazer em resposta à solicitação de um aborto feita por uma mulher. De certa forma, isto é compreensível. Da maneira como as coisas são, não há muito que uma mulher possa fazer com segurança para realizar seu próprio aborto. Então, a pergunta é o que um terceiro pode fazer; o que a mãe pode fazer, quando é mencionado, é deduzido, quase como algo em que se pensa a posteriori, do que se conclui a respeito do que um terceiro pode fazer. Mas me parece que tratar a questão dessa forma é recusar à mãe o mesmo status de pessoa em que se insiste com tanta firmeza em relação ao feto, pois não podemos simplesmente concluir o que uma pessoa pode fazer a partir do que um terceiro pode fazer. Suponha que você esteja presa em uma casa minúscula com uma criança em crescimento. Quero dizer uma casa realmente minúscula e uma criança em crescimento rápido - você já está imprensada contra a parede da casa e em poucos minutos morrerá esmagada. A criança, no entanto, não morrerá esmagada; se nada for feito para deter seu crescimento, ela se machucará, mas, no final, simplesmente arrebentará a casa e ficará livre. Agora, eu poderia muito bem entender se um espectador dissesse: "Não posso fazer nada por você. Não podemos escolher entre a sua vida e a dela, não nos cabe decidir quem vai sair vivo, não podemos intervir". Mas não se pode concluir que você também não pode fazer nada, que você não pode atacar para salvar sua vida. Por mais inocente que a criança seja, você não tem de esperar passivamente até que ela a mate por esmagamento. Uma mulher grávida talvez seja vagamente percebida como se fosse uma casa, à qual não se dá o direito de autodefesa. Mas se a mulher abriga a criança, deve-se lembrar que é uma pessoa que a abriga.

Talvez seja hora de parar e dizer explicitamente que não estou afirmando que as pessoas têm o direito de fazer qualquer coisa para salvar a própria vida. Penso, ao contrário, que o direito de autodefesa tem limites drásticos. Se alguém ameaçar matá-lo caso você não torture outra pessoa até a morte, acho que você não tem o direito de fazer isso nem para salvar sua própria vida. Mas o caso que estamos considerando aqui é muito diferente. No nosso 
caso, só há duas pessoas envolvidas: uma cuja vida é ameaçada e outra que a ameaça. Ambas são inocentes: a que é ameaçada não o é por causa de erro algum; a que ameaça, não o faz por causa de erro algum. Por esta razão, talvez sintamos que, como espectadores, não podemos intervir. Mas a pessoa ameaçada pode.

Em suma, a mulher certamente pode defender sua vida contra a ameaça levantada pela criança que ainda não nasceu, mesmo se isso implica a morte da criança. E isso mostra não apenas que as teses de (1) a (4) são falsas; mostra também que a visão extrema do aborto é falsa e, assim sendo, não precisamos procurar outras maneiras possíveis de chegar a ela a partir do argumento que mencionei no início.

2. A visão extrema poderia, é claro, ser enfraquecida dizendo-se que, embora seja admissível para salvar a vida da mãe, o aborto não pode ser feito por um terceiro, mas só pela própria mãe. Mas isto também não pode ser certo porque o que precisamos ter em mente é que a mãe e a criança que ainda não nasceu não são como dois inquilinos em uma casa pequena que, por um erro lamentável, tivesse sida alugada a ambos: a mãe é a proprietária da casa. Este fato acentua o caráter repugnante da dedução de que a mãe não pode fazer nada a partir da suposição de que um terceiro não pode fazer nada. Mas este fato faz mais do que isso: lança uma luz forte sobre a suposição de que um terceiro não pode fazer nada. Certamente nos faz ver que um terceiro que diz "não posso escolher um de vocês dois" está se iludindo se pensa tratar-se de uma afirmação imparcial. Se Jones encontrou um casaco e o agarrou porque precisa dele para não congelar, mas Smith também precisa do mesmo casaco para não congelar, não é imparcialidade dizer "não posso escolher um de vocês dois" quando Smith é o dono do casaco. As mulheres já disseram repetidas vezes: “Este corpo é o meu corpo!” E têm razão de sentir raiva, razão de sentir que foi como lançar palavras ao vento. Smith, afinal de contas, não ficaria nada contente se lhe disséssemos: "é claro que o casaco é seu, qualquer um reconheceria que é. Mas ninguém pode escolher um de vocês dois, e é Jones que está com o casaco".

Realmente deveríamos perguntar o que significa dizer "ninguém pode escolher" diante do fato de que o corpo que abriga a criança é o corpo da mãe. Pode ser simplesmente a falta de constatação deste fato. Mas pode ser algo mais interessante, ou seja, a noção de que se tem o direito de recusar pôr as mãos nas pessoas, mesmo quando fosse justo fazê-lo, mesmo 
quando a justiça parece exigir que alguém o faça. Assim sendo, a justiça pode dizer a alguém que vá pegar o casaco de Smith de volta de Jones, e mesmo assim você tem o direito de se recusar a ser a pessoa que vai pôr as mãos em Jones, o direito de se recusar a exercer violência física contra ele. Isto, penso eu, deve ser reconhecido. Mas então o que deveria ser dito não é "ninguém pode escolher", e sim só "eu não posso escolher"; na verdade, nem mesmo isso, e sim "eu não vou agir", deixando aberta a possibilidade de que outra pessoa possa ou deva fazê-lo e, em particular, que qualquer um em posição de autoridade, cujo trabalho seja garantir os direitos das pessoas, tanto possa quanto deva fazê-lo. Portanto, isso não é uma dificuldade. Não estou afirmando que qualquer terceiro deva atender a solicitação da mãe de que faça um aborto para salvar a vida dela, mas apenas que pode fazê-lo.

Suponho que, segundo algumas representações da vida humana, o corpo da mãe foi-lhe somente emprestado, sendo que o empréstimo não lhe dá nenhuma prioridade em relação a ele. Os que concordam com este ponto de vista bem podem pensar que é imparcial dizer "eu não posso escolher". Mas simplesmente ignorarei esta possibilidade. Minha própria visão é de que se um ser humano tem alguma prioridade justa em relação a algo, este algo é o seu próprio corpo. E esta afirmação talvez não precise ser defendida, pois, como já apontei, os argumentos contrários ao aborto que estamos examinando reconhecem o direito da mulher de decidir o que acontece em e com seu corpo.

Contudo, embora o reconheçam, tentei mostrar que não levam a sério o que implica reconhecê-lo. Sugiro que a mesma coisa reaparecerá mais claramente quando passarmos, como proponho que façamos agora, dos casos em que a vida da mãe está em jogo aos casos, muitíssimos mais comuns, em que a mulher quer abortar por algum motivo de menor peso do que preservar sua própria vida.

3. Quando a vida da mãe não está em jogo, o argumento que apresentei no início parece ser bastante mais contundente. "Todo mundo tem direito à vida; portanto, a pessoa que ainda não nasceu tem direito à vida”. E o direito da criança à vida não tem mais peso do que tudo mais a não ser o próprio direito da mãe à vida, que ela pode apresentar como fundamento para um aborto?

Esse argumento trata o direito à vida como se este não fosse problemático. Mas ele é, e esta me parece ser precisamente a fonte do erro. 
Pois agora, depois de tantos obstáculos, devemos perguntar o que significa ter direito à vida. Conforme alguns pontos de vista, ter direito à vida inclui ter direito de receber pelo menos o mínimo estritamente necessário à continuidade da vida. Mas suponha que um homem não tem direito algum de receber o que de fato é o mínimo estritamente necessário para que continue a viver? Se eu tiver uma doença que me levará à morte e a única coisa que possa salvar a minha vida é o toque refrescante da mão de Henry Fonda em minha testa febril, nem assim terei direito a receber o toque refrescante da mão de Henry Fonda em minha testa febril. Seria muito incrível da parte dele pegar um avião e vir do Oeste dos EUA para tocar a minha testa. Seria menos bacana, embora, sem dúvida, bem intencionado, se meus amigos pegassem um avião até o Oeste americano e trouxessem Henry Fonda até aqui. Mas eu não tenho direito algum, em relação a ninguém, que o obrigue a fazer isso por mim. Ou, para retornar à história que contei antes, o fato de que, para a continuidade de sua vida, aquele violinista precise do uso contínuo dos seus rins não determina que ele tenha o direito de receber o uso contínuo dos seus rins. Ele certamente não tem o direito, relativamente a você, de obrigar você a conceder a ele o uso contínuo dos seus rins. Porque ninguém tem direito algum ao uso dos seus rins a não ser que você lhe dê esse direito; e ninguém tem direito a demandar que você lhe dê esse direito - se você permitir que ele continue a usar os seus rins será por bondade de sua parte, não algo que ele possa reclamar de você como se lhe fosse devido. Ele também não tem direito algum relativo a ninguém que o permita demandar de outras pessoas que lhe dêem o uso contínuo dos seus rins. Ele certamente não tem o direito de exigir que a Sociedade de Amantes de Música o conecte a você. E se, ao saber que você terá agora de passar nove anos na cama com ele, você agora começar a se desconectar, ninguém no mundo pode tentar impedir o seu ato para que ele assim receba algo que tem direito a receber.

Algumas pessoas são bastante estritas em relação ao direito à vida; do seu ponto de vista, este não inclui o direito de receber nada, mas significa apenas o direito de não ser morto por ninguém. Mas aqui surge uma dificuldade correlata. Se todos devem abster-se de matar aquele violinista, então todos devem abster-se de fazer muitíssimos tipos de coisas. Todos devem abster-se de cortar sua garganta, todos devem abster-se de baleá-lo - e todos devem abster-se de desconectá-lo de você. Mas será que ele tem um direito relativo a todos que lhes exigiria abster-se de desconectar você dele? Abster-se de fazer 
isso é permitir que ele continue a usar os seus rins. Seria possível alegar que ele tem o direito, em relação a nós, que exige que nós permitamos que ele continue a usar os seus rins. Ou seja, ele não tem direito de que lhe demos o uso dos seus rins, mas pode-se alegar que, mesmo assim, ele tem o direito de que agora não intervenhamos e o privemos do uso dos seus rins. Mais adiante voltarei às intervenções de terceiros. Mas o violinista certamente não tem o direito, em relação a você, de exigir que você permita que ele continue a usar os seus rins. Como já disse, se você permitir esse uso, é bondade de sua parte, não algo que você lhe deva.

A dificuldade que aponto aqui não é peculiar ao direito à vida. Coloca-se em relação a todos os outros direitos naturais; e é algo com que uma adequada justificativa de direitos deve lidar. Para os fins do presente trabalho, basta chamar a atenção sobre o tema. Mas eu frisaria que não estou alegando que as pessoas não têm direito à vida; muito pelo contrário, parece-me que o primeiro controle a ser imposto à aceitabilidade de uma justificativa de direitos é que esta justificativa deve apontar como verdade que todas as pessoas têm direito à vida. Estou só alegando que o fato de ter direito à vida não garante que se tenha nem o direito ao uso do corpo de outra pessoa nem o direito de ser autorizado a continuar a usá-lo - nem em caso de precisar dele para a vida em si. Então, o direito à vida não servirá para os oponentes ao aborto da maneira tão simples e clara como eles parecem pensar que serviria.

4. Há outro modo de colocar a dificuldade. No tipo mais comum de caso, privar alguém de algo a que tem direito é tratá-lo injustamente. Suponha que um menino e seu irmão mais novo ganham juntos uma única caixa de chocolates de presente de Natal. Se o mais velho pegar a caixa e não quiser dar nenhum chocolate ao irmão, estará sendo injusto, pois seu irmão recebeu o direito à metade da caixa. Mas suponha que, ao saber que terá de passar nove anos na cama com aquele violinista, você se desconecta dele. Certamente não está sendo injusta com ele, já que não lhe deu direito algum ao uso dos seus rins, e ninguém mais pode dar-lhe um direito desses. Mas temos de observar que, ao desconectar-se, você o está matando; e os violinistas, como todo mundo, têm direito à vida e, portanto, segundo o ponto de vista que estamos examinando neste momento, o direito de não ser morto. Então, aqui você faz algo que ele supostamente tem o direito de que você não faça, mas você não age injustamente em relação a ele ao fazê-lo. 
A correção que pode ser feita a esta altura é: o direito à vida não consiste no direito de não ser morto, e sim no direito de não ser morto injustamente. Aqui corremos o risco de cair em um argumento circular, mas não importa: assim poderíamos compatibilizar o fato de que o violinista tem direito à vida com o fato de que você não age injustamente em relação a ele ao desconectar-se e, assim, matá-lo. Pois se não o mata injustamente, você não está violando seu direito à vida e, portanto, não é surpreendente que não lhe faça injustiça alguma.

Mas, se a correção for aceita, a lacuna no argumento contra o aborto fica bem evidente: não basta, de forma alguma, demonstrar que o feto é uma pessoa, e recordar-nos que todas as pessoas têm direito à vida - também é preciso demonstrar-nos que matar o feto viola o direito deste à vida, i.e., que abortar é matar injustamente. E é de fato?

Suponho que podemos considerar como um dado que, no caso de gestação decorrente de estupro, a mãe não tenha dado à pessoa ainda não nascida o direito ao uso de seu corpo para sua alimentação e abrigo. Mas em que gestação se poderia supor que a mãe tenha dado esse direito à pessoa ainda não nascida? Não é como se houvesse pessoas não nascidas à deriva no mundo, as quais uma mulher que deseja um filho diz "eu te convido a entrar".

Mas pode-se alegar que há outras maneiras pelas quais se pode ter adquirido o direito ao uso do corpo de outra pessoa, fora ter sido convidado por essa pessoa a fazê-lo. Suponha que uma mulher manteve relações sexuais voluntariamente, sabendo da probabilidade de que daí resultasse gestação, e que de fato engravidou; ela não é em parte responsável pela presença - na verdade, pela própria existência - da pessoa não nascida dentro dela? Não há dúvida de que ela não a convidou a entrar. Mas será que sua própria responsabilidade parcial pelo fato de a criança estar ali dá a esta direito ao uso de seu corpo ? $^{7}$ Caso afirmativo, então o aborto seria mais como o caso do menino que leva embora a caixa de chocolates, e menos como o de você se desconectar do violinista - fazê-lo seria privar a pessoa não nascida de algo a que tem direito e, assim, seria cometer uma injustiça.

Então também se pode perguntar se ela pode ou não matá-la, mesmo para salvar sua própria vida: se ela a trouxe voluntariamente à existência, como agora pode matá-la, mesmo em autodefesa?

A necessidade de discutir esse argumento foi colocada por mim aos membros da Society for Ethical and Legal Philosophy, a quem este trabalho foi originalmente apresentado. 
A primeira coisa a dizer a este respeito é que se trata de algo novo. No intuito de determinar que o feto, assim como a mãe, tem direito à vida, os oponentes ao aborto têm-se preocupado tanto em provar sua independência que tendem a não perceber o possível apoio que poderiam obter provando que o feto é dependente da mãe. Isso permitiria determinar que esta tem um tipo especial de responsabilidade por ele, uma responsabilidade que dá ao feto direitos relativos a ela que nenhuma pessoa independente - como um violinista doente, estranho a ela - possui.

Por outro lado, esse argumento só daria à pessoa não nascida o direito ao corpo de sua mãe se a gestação tiver resultado de um ato voluntário, realizado com pleno conhecimento da chance de que uma gestação poderia resultar. Isso excluiria totalmente a pessoa não nascida cuja existência se deve a um estupro. A não ser que algum outro argumento esteja disponível, restaria a conclusão de que pessoas não nascidas cuja existência seja devida a estupro não tem direito ao uso do corpo de sua mãe e que, assim sendo, abortar não é privá-las de nada a que tenham direito e, portanto, não é matar injustamente.

Também devemos notar que não é nada óbvio que esse argumento de fato vá tão longe quanto pretende. Há casos e casos e os detalhes fazem a diferença. Se a sala estiver abafada e, por isso, eu abrir uma janela para ventilá-la e um ladrão entrar, seria absurdo dizer "Ah, agora ele pode ficar, ela lhe deu o direito ao uso de sua casa - pois ela é parcialmente responsável por sua presença ali, já que fez voluntariamente algo que permitiu que ele entrasse, com pleno conhecimento de que os ladrões existem e que os ladrões roubam". Seria ainda mais absurdo dizer isso se eu tivesse grades nas janelas, precisamente para evitar a entrada de ladrões, e um ladrão entrasse só por causa de um defeito nas grades. Continua sendo igualmente absurdo se imaginarmos que não é um ladrão que entra, mas uma pessoa inocente que cai ali dentro por engano. Uma vez mais, suponha que fosse assim: as sementes de pessoas estão à deriva no ar como pólen e, se você abrir a janela, uma pode flutuar para dentro e enraizar-se no seu tapete ou sofá. Você não quer ter filhos, então coloca uma tela fina em suas janelas, a melhor que está ao seu alcance. Acontece, contudo, e isso de fato acontece em raríssimas ocasiões, que uma das telas está com defeito; e uma semente voa para dentro e se enraíza. Será que a pessoa-planta que agora está se desenvolvendo tem direito ao uso da sua casa? Certamente não - apesar de você ter aberto voluntariamente a janela, de saber o que implica ter tapetes e móveis estofados, e de também 
saber que as telas às vezes têm defeitos. Alguém pode alegar que você é responsável pelo enraizamento, que a pessoa-planta tem direito à sua casa porque, afinal de contas, você poderia ter vivido a sua vida com pisos nus e móveis sem estofado ou com janelas e portas trancadas. Mas o argumento também não adianta, pois, da mesma maneira, pode-se evitar a gestação decorrente de estupro fazendo uma histerectomia, ou nunca saindo de casa sem um exército (confiável!).

Parece-me que o argumento que estamos examinando pode estabelecer, no máximo, que existem alguns casos em que a pessoa não nascida tem o direito ao uso do corpo de sua mãe e, portanto, existem alguns casos em que abortar é matar injustamente. Há espaço para muita discussão e debate sobre precisamente quais casos, se é que existe mesmo algum. Mas acho que devemos esquivar-nos desta questão e deixá-la em aberto, pois, de qualquer forma, a argumentação certamente não estabelece que todo aborto signifique matar injustamente.

5. Contudo, há espaço aqui para mais um argumento. Certamente devemos reconhecer que pode haver casos em que seria moralmente indecente separar uma pessoa do seu corpo à custa da vida dessa pessoa. Suponha que você fique sabendo que o violinista não precisa de nove anos da sua vida, mas só de uma hora: para salvar a vida dele, basta você passar uma hora naquela cama com ele. Suponha também que deixá-lo usar os seus rins por aquela uma hora não afetasse nem minimamente a sua saúde. É verdade que você foi sequestrada. É verdade que você não autorizou ninguém a conectá-lo a você. No entanto, parece-me óbvio que você tem que permitir que ele use os seus rins por aquela hora - seria indecente recusar.

Uma vez mais, suponha que a gestação só durasse uma hora, que não representasse ameaça à vida nem à saúde. E suponha que uma mulher engravide em decorrência de um estupro. É verdade que ela não fez nada voluntariamente para gerar a existência de uma criança. É verdade que ela não fez nada, em absoluto, que desse à pessoa não nascida o direito ao uso de seu corpo. Mesmo assim bem se poderia dizer, como na recém-emendada história do violinista, que ela tem que permitir que a pessoa não nascida permaneça ali por aquela hora - que seria indecente recusar.

Algumas pessoas tendem a usar o termo "direito" de tal maneira que daí decorre que você tem de permitir que essa pessoa use o seu corpo durante a hora que precisa, que o violinista tem o direito de usar o seu corpo pela 
hora que precisa, embora esse direito não lhe tenha sido dado por pessoa nem ato algum. Podem dizer que daí também decorre que, se você recusar, estará agindo injustamente em relação a ele. Esse uso do termo talvez seja tão comum que não pode ser chamado de errado; parece-me, no entanto, que se trata de um lamentável afrouxamento do que, a meu ver, seria melhor manter sob rédea curta. Suponha que a caixa de chocolates acima mencionada não tenha sido dada aos dois meninos juntos, mas só ao mais velho. Ali está ele, comendo impassivelmente a caixa toda enquanto seu irmãozinho olha com inveja. Provavelmente diríamos: "Você não deveria ser tão mau. Você deveria dar alguns desses chocolates ao seu irmão". A meu ver, não é verdade que o irmão mais novo tenha direito a chocolate algum. Se o menino se recusar a dar um chocolate ao irmão, estará sendo ganancioso, avarento, insensível - mas não injusto.

Suponho que as pessoas que tenho em mente dirão que o irmão mais novo tem, sim, direito a alguns chocolates e que, portanto, o irmão mais velho estará agindo injustamente se recusar-se a dá-los. Mas, ao dizer isso, se obscurece a distinção que devemos manter, ou seja, a diferença entre a recusa do menino neste caso e sua recusa no caso anterior, em que a caixa foi dada a ambos, e em que o mais novo tinha o que era claramente o direito, sob qualquer ponto de vista, à metade.

Outra objeção a esse uso da expressão "direito", que faz decorrer do fato de que A deveria fazer algo por B o fato de que B tenha o direito de que A faça esse algo por ele, é que este uso vai transformar a questão de se um homem tem ou não direito a uma coisa na pergunta de em que medida é fácil fornecer-lhe essa coisa; e isto me parece não apenas lamentável como também moralmente inaceitável. Vejamos de novo o caso de Henry Fonda. Eu disse acima que eu não tinha direito ao toque de sua mão refrescante em minha testa febril, embora precisasse dele para salvar minha vida. Eu disse que seria muitíssimo bacana da parte dele pegar um avião no Oeste americano para vir tocar minha testa, mas que eu não tinha direito algum em relação a ele neste sentido. Mas suponha que ele não esteja no Oeste dos EUA. Suponha que bastasse ele atravessar o quarto, colocar a mão brevemente em minha testa e minha vida estaria salva. Então ele certamente teria de fazê-lo, e seria indecente recusar. Equivaleria a dizer "Ah, bom, daí decorre que, neste caso, ela tem o direito ao toque de sua mão na testa, e então seria injustiça ele recusar"? Quer dizer que tenho direito quando para ele é fácil 
me proporcionar o toque, mas não tenho direito algum quando é difícil? É uma ideia chocante que os direitos de alguém se desvaneçam e acabem desaparecendo à medida que se torna cada vez mais difícil assegurá-los.

Então, a meu ver, embora você tenha que deixar o violinista usar seus rins pela hora de que necessita, daí não deveríamos concluir que ele tem direito a fazê-lo - deveríamos dizer que, se recusar, você, assim como o menino que tem todos os chocolates e não dá nenhum, seria egocêntrica e insensível, na verdade indecente, mas não injusta. E, de forma similar, mesmo supondo um caso em que a mulher grávida em decorrência de estupro tenha de permitir que a pessoa não nascida use seu corpo pela hora de que necessita, não deveríamos concluir que a pessoa não nascida tenha o direito de fazê-lo; deveríamos concluir que, se recusar, ela será egocêntrica, insensível, indecente, mas não injusta. As queixas não são menos graves; são apenas diferentes. Contudo, não é preciso insistir neste ponto. Se alguém quiser deduzir "ele tem o direito" de "você deveria", então ao mesmo tempo certamente terá de admitir que há casos em que não é uma exigência moral você permitir que aquele violinista use os seus rins, e em que ele não tem o direito de usá-los, e em que, se recusar, você não estará cometendo injustiça alguma contra ele. $\mathrm{O}$ mesmo se aplica a mãe e o filho não nascido. Exceto nos casos em que a pessoa não nascida tem o direito de exigi-lo - e estamos deixando aberta a possibilidade de que possa haver casos assim -, ninguém é moralmente obrigado a fazer grandes sacrifícios - de saúde, de outros interesses e preocupações, de todos os outros deveres e compromissos - por nove anos, ou mesmo por nove meses, no intuito de manter outra pessoa viva.

6. Na verdade, temos de distinguir dois tipos de samaritano: O bom samaritano e o que podemos chamar de samaritano minimamente decente. A história do bom samaritano, como você recordará, é assim:

Um homem descia de Jerusalém a Jericó, e caiu nas mãos de ladrões, que o despojaram; e depois de o terem maltratado com muitos ferimentos, retiraram-se, deixando-o meio morto. Por acaso desceu pelo mesmo caminho um sacerdote, viu-o e passou adiante. Igualmente um levita, chegando àquele lugar, viu-o e passou também adiante. Mas um samaritano que viajava, chegando àquele lugar, viu-o e moveu-se de compaixão. Aproximando-se, atou-lhe as feridas, deitando nelas azeite e vinho; colocou-o sobre a sua própria montaria e levou-o a uma hospedaria e tratou dele. No dia seguinte, tirou dois denários e deu-os ao hospedeiro, dizendo-lhe: Trata dele e, quanto gastares a mais, na volta to pagarei. (Lucas, 10,30-35) 
O bom samaritano desvelou-se, o que lhe impôs algum custo, para ajudar alguém que precisava. Não nos dizem quais eram as opções, isto é, se o sacerdote e o levita poderiam ou não tê-lo ajudado com menos esforço do que o bom samaritano, mas pressupondo que poderiam; então, o fato de não terem feito nada demonstra que não eram nem samaritanos minimamente decentes, não porque não fossem samaritanos, mas porque não eram nem minimamente decentes.

Essas coisas são uma questão de grau, é claro, mas há uma diferença, que talvez fique mais evidente na história de Kitty Genovese, que, como vocês se lembrarão, foi assassinada enquanto 38 pessoas olhavam ou ouviam e não fizeram nada para ajudá-la. Um bom samaritano teria se apressado em ajudá-la diretamente, contra o assassino. Ou talvez seja melhor dizer que, para fazer isto, teria sido um esplêndido samaritano, já que estaria enfrentando o risco de morrer. Mas as 38 pessoas não só não fizeram isso como nem se deram ao trabalho de pegar o telefone e ligar para a polícia. $\mathrm{O}$ samaritano minimamente decente teria pelo menos telefonado, e o fato de eles não o terem feito foi monstruoso.

Depois de contar a história do bom samaritano, Jesus disse: "Vai, e faze tu o mesmo". Talvez ele tenha querido dizer que somos moralmente obrigados a agir como o bom samaritano. Talvez estivesse instando as pessoas a fazerem mais do que lhes é moralmente exigido. Seja como for, parece óbvio que nenhum dos 38 estava moralmente obrigado a correr para dar ajuda direta arriscando a própria vida, e que ninguém está moralmente obrigado a dar longos períodos de sua vida - nove anos ou nove meses - para manter a vida de uma pessoa que não tenha direito especial algum (estamos deixando aberta esta possibilidade) a exigi-lo.

De fato, com um tipo bastante impressionante de exceção, ninguém, em país algum do mundo, está legalmente obrigado a fazer nada próximo a isto por nenhuma outra pessoa. O tipo de exceção é óbvio. Minha principal preocupação aqui não é o estado da legislação relativa ao aborto, mas vale a pena chamar a atenção para o fato de que em nenhum estado dos EUA homem algum é obrigado por lei a ser sequer um samaritano minimamente decente para ninguém; não existe lei que permita processar as 38 pessoas que assistiram passivamente ao assassinato de Kitty Genovese. Na maioria dos estados americanos, em contraste, as mulheres são obrigadas por lei a serem não apenas samaritanas minimamente decentes, mas boas samari- 
tanas para uma pessoa ainda não nascida que está dentro delas. Isto não resolve nada, nem em um sentido nem no outro, porque seria possível alegar que deveria haver leis nos EUA - como existem em muitos países europeus - que obrigassem as pessoas a serem pelo menos samaritanos minimamente decentes. ${ }^{8}$ Mas isso mostra que existe uma injustiça grosseira no atual estado da lei. E também mostra que os grupos que atualmente militam contra a liberalização das leis do aborto, que na verdade trabalham para que seja declarado inconstitucional que algum estado permita o aborto, fariam melhor se começassem a trabalhar pela aprovação de leis do bom samaritano de maneira geral, ou que aceitassem a acusação de que estão agindo de má fé.

Pessoalmente, penso que as leis do samaritano minimamente decente seriam uma coisa, as leis do bom samaritano, outra bem diferente e, na verdade, nada apropriadas. Mas aqui não estamos preocupados com a lei. O que devemos perguntar não é se ninguém deveria ser obrigado por lei a ser bom samaritano, mas se devemos aceitar uma situação na qual alguém está sendo obrigado - pela natureza, talvez - a ser bom samaritano. Em outras palavras, agora temos de examinar as intervenções de terceiros. Estou argumentando que ninguém é moralmente obrigado a fazer grandes sacrifícios para manter a vida de outro que não tenha o direito de exigi-lo, e isto mesmo quando o sacrifício não inclua a vida em si; não somos moralmente obrigados a ser bons samaritanos nem ótimos samaritanos uns para os outros. Mas e se um homem não conseguir livrar-se de uma situação dessas? E se ele recorrer a nós para que o livremos? Parece-me claro que há casos em que podemos fazê-lo, casos em que um bom samaritano o livraria. Ali está você, sequestrada e tendo nove anos na cama com aquele violinista pela frente. Você tem sua própria vida para viver. Você lamenta, mas simplesmente não se imagina abrindo mão de uma parte tão grande de sua vida para manter a dele. Você não consegue se livrar da situação e pede que façamos isso. Eu deveria ter pensado que, à luz do fato de ele não ter direito de usar o seu corpo, seria óbvio que não temos de aceitar que você seja forçada a abrir mão de tanto. Podemos fazer o que você pede. Ao fazê-lo, não estamos cometendo injustiça contra o violinista.

7. Seguindo a pista dos oponentes ao aborto, tenho falado até agora do feto meramente como uma pessoa e o que estou perguntando é se o argumento

8 Para uma discussão das dificuldades envolvidas e um estudo da experiência europeia com essas leis, ver Ratcliffe, ed. (1966). 
com que começamos, que procede somente quando se considera o feto uma pessoa, realmente prova sua própria conclusão. Aleguei que não o faz.

Mas é claro que há argumentos e argumentos, e é possível dizer que eu simplesmente me apeguei ao argumento errado. Pode-se dizer que o importante não é o mero fato de o feto ser uma pessoa, mas que é uma pessoa em relação à qual a mulher tem um tipo especial de responsabilidade decorrente do fato de ser sua mãe. E se pode alegar que, portanto, nenhuma das minhas analogias procede - pois você não tem esse tipo especial de responsabilidade para com o violinista, Henry Fonda não tem esse tipo especial de responsabilidade para comigo. E a nossa atenção pode ser atraída para o fato de que tanto os homens quanto as mulheres são obrigados por lei a dar sustento a seus filhos.

Tratei (brevemente) desse argumento na Seção 4, acima; mas agora seria o caso de fazer uma recapitulação (ainda mais breve). Sem dúvida, só temos essa "responsabilidade especial" por uma pessoa se a tivermos assumido, explícita ou implicitamente. Se determinados pais não tentam evitar a gravidez, não procuram abortar e, no momento do nascimento do bebê, não o entregam para adoção, mas o levam para casa com eles, então eles assumiram a responsabilidade pela criança, deram-lhe direitos, e agora não podem retirar seu apoio a ela, o que lhe custaria a vida, porque agora acham difícil sustentá-la. Mas, se tiverem tomado todas as precauções razoáveis para não ter filhos, esses pais não têm, simplesmente em virtude de sua relação biológica com a criança que vem ao mundo, uma responsabilidade especial para com ela. Podem desejar assumir essa responsabilidade, ou podem não desejar fazê-lo. E estou sugerindo que, se o fato de assumir a responsabilidade por ela exigir grandes sacrifícios, eles podem recusar. Um bom samaritano - ou, pelo menos, um Esplêndido samaritano - não recusaria, mesmo se os sacrifícios a serem feitos fossem enormes. Mas um bom samaritano também assumiria a responsabilidade por aquele violinista; assim também Henry Fonda, se fosse um bom samaritano, pegaria um avião no Oeste dos EUA e assumiria responsabilidade por mim.

8. Muitos dos que querem encarar o aborto como moralmente aceitável acharão meu argumento insatisfatório sob dois aspectos. Primeiro, alego que o aborto não é inadmissível, mas não alego que seja sempre admissível. Pode muito bem haver casos em que, para levar a gestação a termo, seja preciso apenas uma mãe samaritana minimamente decente, e este é um 
padrão abaixo do qual não devemos cair. Tendo a considerar um mérito do meu relato precisamente o fato de que não pronuncia um sim geral nem um não geral. Dá espaço e apoio à nossa percepção de que, por exemplo, uma estudante de catorze anos de idade, doente e morta de medo, grávida devido a um estupro, pode, é claro, escolher abortar, e que qualquer lei que elimine esta possibilidade é uma lei insana. E também dá espaço e apoio à nossa percepção de que, em outros casos, recorrer ao aborto é, com certeza, até indecente. Seria indecente a mulher solicitar um aborto, e indecente um médico realizá-lo, se ela estiver no sétimo mês e quiser abortar só para evitar o incômodo de adiar uma viagem ao exterior. O próprio fato de os argumentos que destaquei tratarem todos os casos de aborto, ou mesmo todos os casos de aborto em que a vida da mãe não está em jogo, como moralmente equivalentes deve tê-los tornado suspeitos de início.

Em segundo lugar, estou argumentando a favor da admissibilidade do aborto em alguns casos, mas não estou argumentando a favor do direito de fazer com que a criança ainda não nascida morra. É fácil confundir essas duas coisas, na medida em que, até certo ponto de sua vida, o feto não é capaz de sobreviver fora do corpo da mãe; portanto, tirá-lo de seu corpo faz com que morra. Mas há diferenças importantes entre ambos os casos. Afirmei que você não é moralmente obrigada a passar nove meses na cama mantendo a vida daquele violinista; mas afirmar isso não significa, de modo algum, dizer que se, quando você se desconectar, houver um milagre e ele sobreviver, você tem o direito de se virar e cortar a garganta dele. Você pode desconectar-se mesmo se isso custar a vida dele; você não pode fazer com que ele morra, por algum outro meio, se o fato de desconectar-se dele não o matar. Algumas pessoas ficarão insatisfeitas com esta característica da minha argumentação. Uma mulher pode ficar arrasada pela ideia de uma criança, um pedacinho dela, ser dada em adoção, pois assim nunca mais a verá nem terá notícias dela. Portanto, ela pode querer não apenas que a criança seja desconectada dela, porém mais, que morra. Alguns oponentes ao aborto tendem a considerar isto algo abaixo de desprezível - assim mostrando insensibilidade em relação ao que certamente é uma poderosa fonte de desespero. Mesmo assim, concordo que o desejo de que a criança morra não deve ser satisfeito por ninguém se for possível desconectar a criança viva. A esta altura, contudo, deve-se recordar que, no transcurso deste texto, eu apenas fiz de conta que o feto é um ser humano desde o momento da concepção. Um aborto muito 
precoce certamente não está matando uma pessoa e, portanto, este caso não é tratado em nada do que eu disse aqui.

\title{
Referências bibliográficas
}

CALLAHAN, Daniel. 1970. Abortion: law, choice and morality. New York: Macmillan.

Encyclical letter of Pope Pius XI on Christian marriage. S.d. Boston: St. Paul. FELDMAN, David M. 1968. Birth control in Jewish law. New York: New York University Press.

NOONAN JR., John T. 1970 . "An almost absolute value in history". In: NOONAN JR., John T. ( e d.). The morality of abortion. Cambridge: Harvard University Press.

RATCLIFFE, James M. (ed.). 1966. The good Samaritan and the law. New York: Anchor Books.

\section{Resumo}

O artigo analisa os argumentos contrários ao direito da mulher à interrupção voluntária da gravidez, fundamentando assim sua posição em defesa do direito ao aborto. A análise das contradições nos discursos do "direito à vida" ultrapassa as situações nas quais há risco de morte da mãe ou nas quais a gravidez decorreu de estupro. A consideração da mãe como pessoa moral inclui, na posição sustentada no texto, o direito a assegurar a própria vida e a escolher como esta vida será vivida. Nesta análise, o aborto é discutido em suas implicações políticas, morais e filosóficas.

Palavras-chave: aborto; direito à vida; indivíduo; obrigação moral; gestação; escolha.

\begin{abstract}
The article examines arguments opposing women's right to voluntary interruption of pregnancy, thus basing its own stance in favor of the right to abortion. Examination of contradictions in "right to life" discourses goes beyond life-threatening situations or pregnancies resulting from rape. Considering the mother as a moral person includes, in the stance sustained in the text, the right to guarantee her own life and to choose how it is going to be lived. In this analysis, abortion is debated for its political, moral, and philosophical implications.
\end{abstract}

Key words: abortion; right to life; individual; moral obligation; pregnancy; choice. 